\title{
28. THE OCCURRENCE, ABUNDANCE, AND COMPOSITION OF ICE-RAFTED DEBRIS IN SEDIMENTS FROM DEEP SEA DRILLING PROJECT SITES 579 AND 580, NORTHWEST PACIFIC ${ }^{1}$
}

\author{
Lawrence A. Krissek, Oregon State University \\ Joseph J. Morley, Lamont-Doherty Geological Observatory of Columbia University \\ and \\ Darlene K. Lofland, Washington State University ${ }^{2}$
}

\begin{abstract}
The abundance and composition of the coarse-sand fraction $(250 \mu \mathrm{m}-2 \mathrm{~mm})$ of samples from Deep Sea Drilling Project Sites 579 and 580 were investigated to determine the chronology of ice rafting at these locations.

The ice-rafting signal at these sites is reduced relative to the generalized ice-rafting chronology of the North Pacific (Kent et al., 1971) because of increased distance to the ice-rafting source areas. These data, however, do record the general increase in ice-rafting importance as sediment age decreases, especially between 0 and $1.0 \mathrm{~m} . \mathrm{y}$. ago. In addition, peaks in ice-rafting importance since $1.0 \mathrm{~m}$.y. ago at Sites 579 and 580 are generally synchronous with periods of major ice-rafting influence throughout the North Pacific. The first occurrence of ice-rafted debris at the Matuyama/Gauss magnetic boundary supports a proposed age of approximately $2.47 \mathrm{~m}$.y. for the onset of major Northern Hemisphere glaciation.

The coarse-sand fraction at Sites 579 and 580 contains a significant component of non-ice-rafted material, particularly biogenic particles and volcanic pumice. Under these conditions, the standard assumption that the weight percent of the coarse-sand fraction reflects variations in ice-rafting importance may not be valid. For samples taken at some distance from the source of ice-rafted debris, both the abundance and the composition of the coarse-sand fraction must be considered to obtain a valid measure of the influence of sediment transport via ice rafting.
\end{abstract}

\section{INTRODUCTION}

A series of studies of the coarse-sediment fraction $(>63 \mu \mathrm{m})$ from a number of Deep Sea Drilling Project (DSDP) sites and piston cores (Griggs and Kulm, 1969; Conolly and Ewing, 1970; Kent et al., 1971; von Huene et al., 1973, 1976) have outlined in some detail the lateral and temporal distribution of ice-rafted debris (IRD) in the North Pacific Ocean. These studies have used the abundance of a particular sand-size fraction as an indicator of the relative importance of transport via ice-rafting at the time of deposition (see the Methods section). Downcore variations in the abundance of that size fraction, and therefore in the importance of ice rafting, were interpreted as indicators of general hemispheric climatic conditions. Increases in the abundance of IRD indicate times of continental glaciation, whereas decreases in IRD abundance reflect periods of climatic warming. In addition, IRD composition was determined qualitatively to reveal sediment source areas; these data were used to outline paleoceanographic circulation patterns.

Of direct importance to this study are the works of Conolly and Ewing (1970) and Kent et al. (1971). Conolly and Ewing (1970) used coarse-fraction data from 22 Vema piston cores to delineate the horizontal and vertical distribution of IRD in the northwest Pacific Ocean.

\footnotetext{
${ }^{1}$ Heath, G. R., Burckle, L. H., et al., Init. Repts. DSDP, 86: Washington (U.S. Govt. Printing Office).

2 Addresses: (Krissek, present address) Department of Geology and Mineralogy, Ohio State University, Columbus, OH 43210; (Morley) Lamont-Doherty Geological Observatory of Columbia University, Palisades, NY 10964; (Lofland) Department of Geology, Washington State University, Pullman, WA 99163.
}

In these samples, the first IRD is younger than approximately $2.2 \mathrm{~m}$.y.; IRD becomes common in sediments younger than $1.5 \mathrm{~m}$.y. and abundant in horizons younger than 1.0 m.y. Up to six major IRD zones occur within the Brunhes Normal Epoch (Conolly and Ewing, 1970), but limited magnetostratigraphic control prevented the development of a more detailed IRD chronologv. Horizontal distribution and composition of the IRD suggests source areas in the Kurile-Kamchatka-Aleutian arc, with dispersal by a Pleistocene current system similar to the one now in existence (Fig. 1).

Coarse-fraction samples from three of the Vema cores studied by Conolly and Ewing (1970), three additional Vema cores, and three Robert Conrad cores were investigated further by Kent et al. (1971). In combination with detailed paleomagnetic, biostratigraphic, and tephrochronologic age control, IRD abundances in these cores were converted into a generalized chronology of relative ice-rafting importance in the North Pacific. Four periods of increased rafting were identified between 1.2 and $2.5 \mathrm{~m}$.y. ago, whereas at least 11 such intervals were identified from $1.2 \mathrm{~m}$.y. ago to the present. Included in these 11 are the 6 IRD-rich zones identified by Conolly and Ewing (1970).

More recent studies of ice-rafting in the North Pacific have concentrated on sediments obtained during DSDP Leg 18 at Sites 178, 179, 180, and 183 in the Gulf of Alaska (von Huene et al., 1973, 1976). Age control for these samples was very good, but the establishment of an ice-rafting chronology was hampered by core recovery of less than $50 \%$ of the drilled sections (von Huene et al., 1976). As a result, the major conclusions of von 


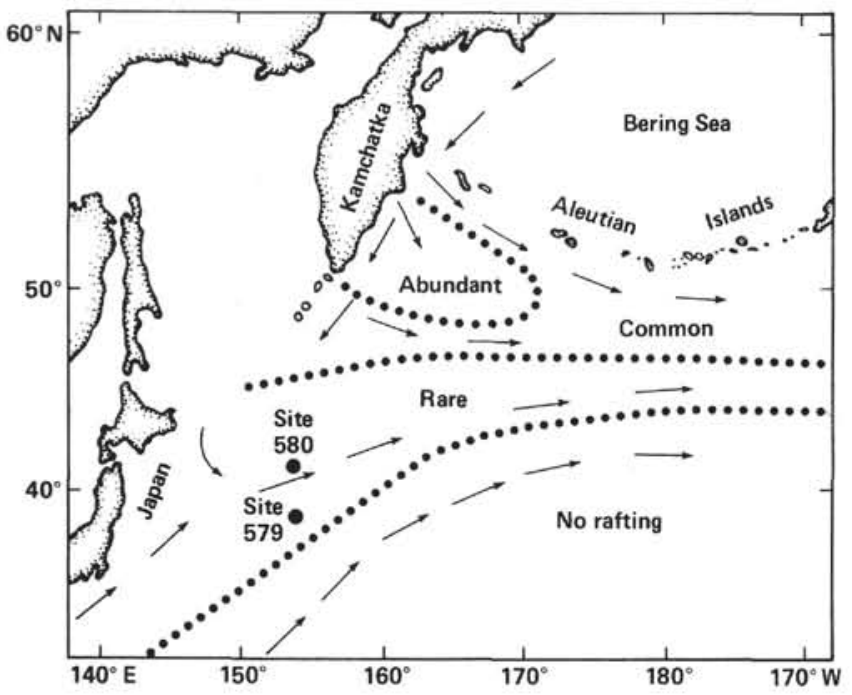

Figure 1. Map of the northwest Pacific Ocean, showing the locations of Sites 579 and 580. Major surface currents (northward-flowing Kuroshio, southward-flowing Oyashio, eastward-flowing West Wind Drift) and zones of occurrence of ice-rafted debris modified from Conolly and Ewing (1970).

Huene et al. (1973) were that (1) the coarse-sand fraction $(250 \mu \mathrm{m}-2 \mathrm{~mm})$ is ice transported in origin and (2) the duration of periods of ice erratic influx is approximately 10,000 to 20,000 yr. Further work with these data, in conjunction with data from one of the Vema cores, allowed the generation of an IRD chronology curve for the past 300,000 yr. in the Gulf of Alaska (von Huene et al., 1976); this curve showed a positive correspondence with variations in other Northern Hemisphere climatic indicators during the same period.

In summary, the studies outlined above have:

1. Concluded that abundances of continentally derived sand-sized material in deep-sea sediments of the North Pacific do indicate relative importance of transport via ice rafting at the time of deposition,

2. Concluded that the coarse-sand fraction $(250 \mu \mathrm{m}-$ $2 \mathrm{~mm}$ ) is transported predominantly by icebergs (at least near source areas, e.g., the Gulf of Alaska),

3. Established a generalized chronology of IRD abundance for the North Pacific which can be interpreted as a climatic record back to approximately 2.5 m.y. ago, and

4. Concluded that general paleocirculation patterns in the North Pacific have been relatively constant from at least the Pleistocene to the present.

Additional sediments with a potential North Pacific IRD signal were recovered during DSDP Leg 86. As shown in Figure 1, Sites 579 and 580 were located within the zone of "rare" IRD occurrence as outlined by Conolly and Ewing (1970). However, the high recovery rate $(86-94 \%$ at Site $579,91 \%$ at Site 580 ; see Site 579 and Site 580 chapters, this volume) of relatively undisturbed sediments with the hydraulic piston corer (HPC), combined with detailed paleomagnetic and biostratigraphic age control, suggested that the IRD signal, although weak, should be discernible at these sites. As a result, this study was undertaken with two major objectives. The first objective was to determine the temporal abun- dance of IRD in sediments recovered at Sites 579 and 580 , in order to establish an IRD chronology for the northwest Pacific Ocean. This chronology was then compared to the generalized North Pacific chronology of ice-rafting influence published by Kent et al. (1971); the two chronologies generally show synchronous variations, although the signal from Sites 579 and 580 is less complete because of increased transport distance. The second objective was to evaluate the use of the coarse sand $(250 \mu \mathrm{m}-2 \mathrm{~mm})$ weight percent as an indicator of IRD abundance. Although this approach may be valid near IRD source areas (i.e., the Gulf of Alaska; von Huene et al., 1973), our data suggest that such an assumption may not be valid near the boundaries of ice-rafting influence.

\section{METHODS AND ANALYSES}

Samples were taken for IRD analysis at intervals of approximately $100 \mathrm{~cm}$, from Cores 1 through 12 at Site 579 and from Cores 1 through 17 at Site 580 . A total of 121 samples from Site 579 were analyzed, and 142 samples from Site 580 were analyzed. On the basis of sedimentation rates of 40 to $50 \mathrm{~m} / \mathrm{m}$.y. (see Site 579 and Site 580 chapters, this volume), the sampling interval is estimated at approximately 20,000 yr. (Table 1). This interval is equivalent to that used by Conolly and Ewing (1970) and Kent et al. (1971). Because of the 20,000-yr. sampling interval, these data are not suitable for the examination of high-frequency climatic fluctuations; they are valuable, however, in delineating major, long-term changes.

In order to be most consistent with previous investigations, the 250 $\mu \mathrm{m}-2 \mathrm{~mm}$ grain-size interval was chosen as the indicator of IRD abundance in sediments from Sites 579 and 580 (Table 1). Samples were dried at $60^{\circ} \mathrm{C}$, weighed, disaggregated ultrasonically, and wet-sieved at $2 \mathrm{~mm}$ and $250 \mu \mathrm{m}$. The $250 \mu \mathrm{m}-2 \mathrm{~mm}$ grain-diameter fraction was then dried, weighed, and examined under a binocular microscope to determine qualitatively the abundances of various sediment components. The grains were classified as biogenic (predominantly radiolarians), volcanic, or ice rafted in origin on the basis of appearance and gross surface texture. Several samples from Site 580 were not successfully dispersed by the ultrasonic technique following initial weighing, so an additional group of undisaggregated particles ("mudballs") was also recognized. A major problem in classifying grains was the discrimination of pumice grains transported solely by wind from those transported by a combination of wind and ice. In this study, the occurrence of pumice independent of other IRD grains, the fresh appearance of the pumice grains, and the location of these sites several hundred kilometers downwind from a major volcanic chain all support an interpretation of direct eolian transport for most of the pumice grains observed at Sites 579 and 580 . As a result, the coarse sands were subdivided into biogenic, volcanic, ice-rafted, and undisaggregated components. Compositionally, grains classified as IRD included quartz, feldspar, and lithic fragments of mudstones, granite, andesite, and basalt.

\section{RESULTS AND DISCUSSION}

The coarse-sand fraction abundance and compositional data are tabulated in the Appendix. Porosity and bulkdensity data for these samples are given elsewhere in this

Table 1. Summary of analytical techniques (size fraction and sampling intervals) employed in various studies of ice-rafted debris in the North Pacific.

\begin{tabular}{|c|c|c|c|}
\hline $\begin{array}{l}\text { Coarse fraction } \\
\text { measured }\end{array}$ & $\begin{array}{l}\text { Sampling } \\
\text { interval }(\mathrm{cm})\end{array}$ & $\begin{array}{l}\text { Approximate sampling } \\
\text { interval (yr.) }\end{array}$ & Reference \\
\hline $\begin{array}{c}>62 \mu \mathrm{m} \text { multiplied by IRD } \\
\% \text { in }>62 \mu \mathrm{m} \text { fraction } \\
\text { from point count data. }\end{array}$ & $10-30$ & $20,000-100,000$ & Conolly and Ewing (1970) \\
\hline $250 \mu \mathrm{m}-7 \mathrm{~mm}$ & 10 & 17,000 & Kent et al. (1971) \\
\hline $250 \mu \mathrm{m}-2 \mathrm{~mm}$ & $20-50$ & 3,000 & von Huene et al. (1973) \\
\hline $250 \mu \mathrm{m}-2 \mathrm{~mm}$ & $20-50$ & 3,000 & von Huene et al. (1976) \\
\hline $250 \mu \mathrm{m}-2 \mathrm{~mm}$ & 100 & 20,000 & This study \\
\hline
\end{tabular}


volume (see Site 579 and Site 580 chapters and Schultheiss, this volume). Relative abundance data for the coarse-sand fraction (wt. $\%$ in the $250 \mu \mathrm{m}-2 \mathrm{~mm}$ interval) in samples from Sites 579 and 580 are plotted in Figure 2 as a function of sub-bottom depth. Values from Site 579 range from 0 to $6.5 \%$ with an average of $0.12 \%$; values from Site 580 range from 0 to $1.18 \%$, with an average of $0.15 \%$. The patterns of coarse-fraction abundance are fairly irregular in both cases, with many highs and lows defined by single data points. Several general observations, however, can be made:

1. Above-average coarse-fraction abundances at Site 579 are most common between 10 and $28 \mathrm{~m}$ sub-bottom, with other major abundance peaks at $42 \mathrm{~m}, 67-$ $76 \mathrm{~m}$, and 87-104 m sub-bottom.

2. Coarse-fraction abundance at Site 579 shows no long-term trend of increase or decrease downcore.

3. Most of the coarse sand sampled at Site 579 is biogenic or volcanic in origin; zones containing IRD occur at $17-25,42,61$, and possibly $90 \mathrm{~m}$ downcore.

4. Within the zones at Site 579 where IRD does occur, the relative importance of the IRD within the coarse fraction generally decreases downcore.

5. Above-average coarse-fraction abundances at Site 580 are most common in the intervals $0-24 \mathrm{~m}, 37-56 \mathrm{~m}$, 70-90 $\mathrm{m}$, and $102-113 \mathrm{~m}$ sub-bottom.

6. Data from Site 580 samples show a long-term decrease in coarse-fraction abundance downcore, interrupted by the shorter intervals of increase listed above.

7. Composition of the coarse fraction changes downcore, from an IRD-biogenic-pumice assemblage above

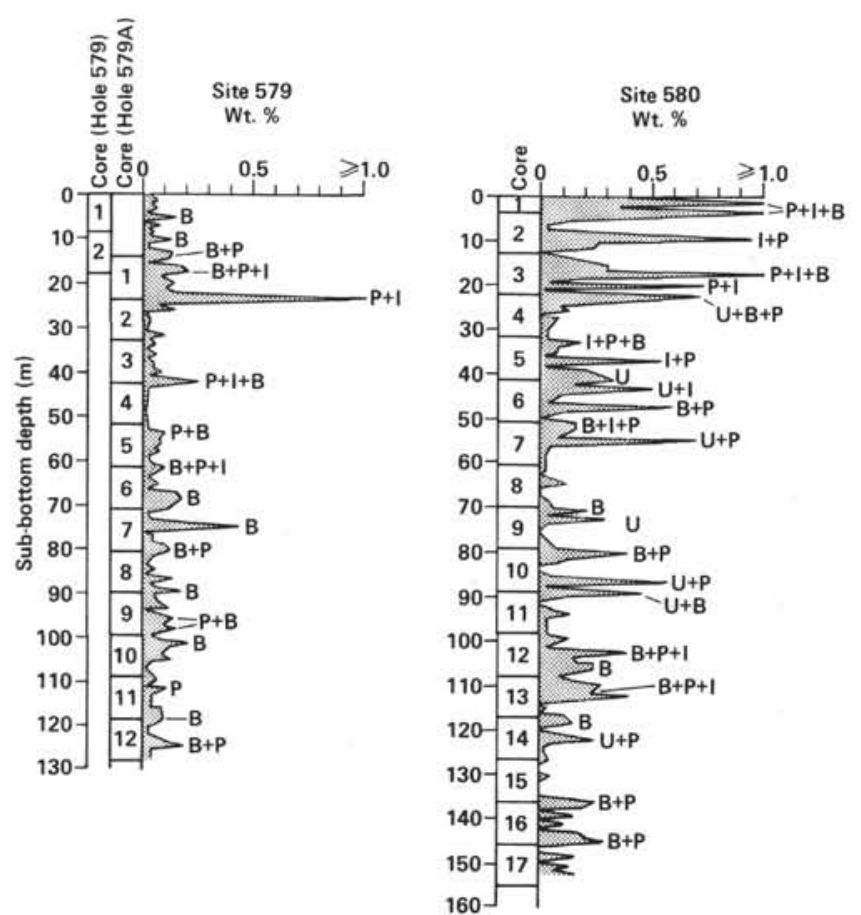

Figure 2. Abundance and composition of the coarse-sand fraction (wt. \% of the $250 \mu \mathrm{m}-2 \mathrm{~mm}$ size fraction) downcore at Sites 579 and 580. Coarse sands are classified as biogenic particles (B), pumpice $(\mathrm{P})$, ice-rafted debris (I), or undisaggregated clays $(\mathrm{U})$ and are listed in order of decreasing importance for each peak.
$45 \mathrm{~m}$ sub-bottom to a predominantly biogenic-pumiceundisaggregated material assemblage with minor IRD below that level.

A major point illustrated by Figure 2 is the predominance of non-IRD grains in the $250 \mu \mathrm{m}-2 \mathrm{~mm}$ fraction of these samples. Based on point counts, volcanic pumice and biogenic particles form the majority of grains present (see Appendix). Although this analysis does not consider differences in density between volcanic, biogenic, and ice-rafted particles, the data presented in Figure 2 indicate that many of the samples with abundant coarse sand contain essentially no IRD grains. These results suggest that a detailed study considering coarsesand abundance, mode of particle origin, and particle density will be needed to determine quantitatively the abundance of IRD (measured as wt. \% of the sample) in these sediments. The data presently available, however, do indicate that non-ice-transported grains form a significant component of the coarse sands; as such, the conclusion of von Huene et al. (1973) that the weight percent of the $250 \mu \mathrm{m}-2 \mathrm{~mm}$ fraction serves as a reliable indicator of ice-rafting importance may not be valid away from the source areas of ice rafting.

By combining the IRD abundance data contained in Figure 2 with the linear sedimentation rates calculated for Sites 579 and 580 from paleomagnetic and biostratigraphic data (see Site 579 and Site 580 chapters and Bleil, this volume), qualitative chronologies of ice-rafting influence at these sites can be constructed. These chronologies are shown in Figure 3, with the generalized North Pacific chronology of Kent et al. (1971) for comparison. Since the uncertainty of an age assignment increases as the total age increases, discrepancies between chronologies are not unexpected, especially for the older horizons.

Three general conclusions may be drawn from the data presented in Figure 3. The first conclusion is that the IRD records at Sites 579 and 580 agree well with the generalized ice-rafting curve of Kent et al. (1971) for sediments younger than approximately $1.0 \mathrm{~m} . \mathrm{y}$. Within the limits of age determinations based on shipboard paleomagnetic and biostratigraphic data, the times of increased ice-rafting importance at Sites 579 and 580 can be correlated with times of increased rafting in the general North Pacific curve for sediments younger than $1.0 \mathrm{~m}$.y. In fact, the increases at Site 580 reflect the major events of the generalized chronology. The record at Site 579, however, is lower in amplitude and does not correlate quite as well with the general North Pacific chronology for sediments less than $1 \mathrm{~m}$.y. old. A significant loss of information occurs between both the northern North Pacific (where Kent et al. [1971] obtained their data) and Site 580 and between Sites 580 and 579 . Such a loss is expected because of increased distance from the proposed IRD source in the Kurile-Kamchatka-Aleutian region. Estimates of the paleopositions of Sites 579 and 580 for the past 1 m.y. suggest a WNW movement of approximately $78 \mathrm{~km}$ during this time (Table 2). Backtracking these two sites places Site 579 very close to the boundary between "rare" and "no rafting" regions established by Conolly and Ewing (1970; Fig. 1), 


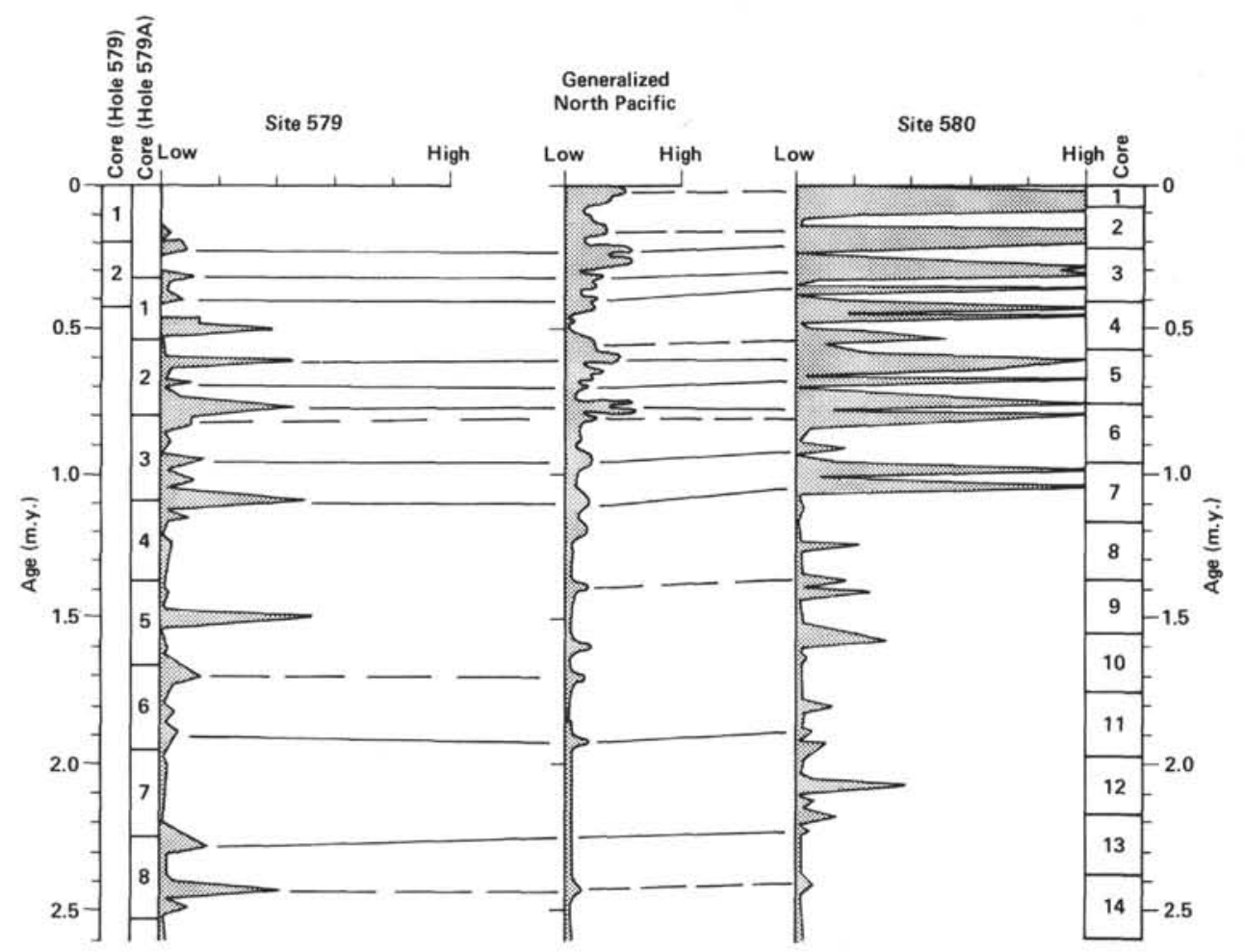

Figure 3. Chronologies of relative ice-rafting influence at Sites 579 and 580 , with the generalized North Pacific chronology of Kent et al. (1971) for comparison. Ages were determined using sedimentation rates given in the Site 579 and Site 580 chapters and Bleil (this volume). Dashed lines are preliminary correlations based on the age data. Solid lines are preliminary correlations based on age data and supported by radiolarian abundances (Morley, this volume).

Table 2. Estimates of paleopositions of Sites 579 and 580 for the past 2.5 m.y.

\begin{tabular}{|c|c|c|c|c|c|}
\hline \multirow[b]{2}{*}{$\begin{array}{c}\text { Age } \\
\text { (m.y.) }\end{array}$} & \multicolumn{2}{|c|}{ Site 579} & \multirow{2}{*}{$\begin{array}{l}\text { Distance from } \\
\text { present position } \\
(\mathrm{km})\end{array}$} & \multicolumn{2}{|c|}{ Site 580} \\
\hline & $\begin{array}{l}\text { Latitude } \\
\left({ }^{\circ} \mathrm{N}\right)\end{array}$ & $\begin{array}{l}\text { Longitude } \\
\left({ }^{\circ} \mathrm{E}\right)\end{array}$ & & $\begin{array}{l}\text { Latitude } \\
\left({ }^{\circ} \mathrm{N}\right)\end{array}$ & $\begin{array}{c}\text { Longitude } \\
\left({ }^{\circ} \mathrm{E}\right)\end{array}$ \\
\hline 0 & 38.63 & 153.84 & 0 & 41.62 & 153.98 \\
\hline 0.5 & 38.48 & 154.24 & 38.8 & 41.32 & 154.40 \\
\hline 1.0 & 38.33 & 154.64 & 77.6 & 41.02 & 154.82 \\
\hline 1.5 & 38.18 & 155.04 & 116.4 & 40.87 & 155.24 \\
\hline 2.0 & 38.03 & 155.44 & 155.2 & 40.72 & 155.66 \\
\hline 2.5 & 37.88 & 155.84 & 194.0 & 40.57 & 156.08 \\
\hline
\end{tabular}

Note: Estimates based on rates of motion northward $=33.35 \mathrm{~km} / \mathrm{m} . \mathrm{y}$. and westward $=70.04 \mathrm{~km} / \mathrm{m} . \mathrm{y}$. (van Andel et al., 1975; Leinen and Heath, 1981; Bleil, this volume).

while Site 580 remains well within the region of rare rafting. As a result, the better IRD record upcore at Site 579 may reflect both climatic variations and the change in location of Site 579 through time, while climatic variations are the sole control on the IRD record at Site 580 . In summary, the IRD chronologies at Site 579 and 580, for sediments younger than 1.0 m.y., are incomplete relative to the general North Pacific chronology; the chronology at Site 580, however, appears to record the major events that influenced the region.

The second observation about the data in Figure 3 is that the IRD record at Sites 579 and 580 is relatively poor before $1.0 \mathrm{~m} . \mathrm{y}$. ago. Fewer IRD increases occur between 1.0 and 2.0 m.y. ago than in the younger sedi- ments, and the peaks in the Site 580 and Site 579 sequences that do occur are generally weaker than the peaks in sequences younger than 1.0 m.y. As such, they may reflect rare or random rafting influence or may be the result of misidentification of detrital grain origin. The generalized North Pacific chronology also indicates a significant decrease in ice-rafting importance at this time; the decrease observed closer to the source by Kent et al. (1971) is synchronous with the major loss of IRD further to the south at Sites 579 and 580 . Estimates of paleopositions suggest that Sites 579 and 580 moved WNW from approximately 194 to $78 \mathrm{~km}$ away from their present positions during the interval from 2.5 to 1.0 m.y. ago (Table 2). Backtracking these two sites places Site 579 essentially at the boundary between the "rare" and "no rafting" regions of Conolly and Ewing (1970; Fig. 1), while Site 580 moves close to that boundary. As a result, the decreased IRD signal at Site 579 may reflect both site location and climatic variation controls during this time, while the decreased IRD signal at Site 580 is controlled predominantly by climatic fluctuations. At this point, it is necessary to emphasize again the 20,000-yr. sampling interval for the data. If intervals of IRD influx have a duration of only 10,000 to 20,000 yr. (von Huene et al., 1973), then short-duration increases may be missed totally by the samples used in this study. In addition, the relatively long sampling period eliminates much of the detail seen throughout the generalized North Pacific curve. 
The final conclusion based on these data is that ice rafting in the North Pacific began at or before approximately 2.4 to $2.5 \mathrm{~m}$.y. ago. The earliest IRD occurrence at Site 579 is dated at approximately 2.49 m.y. ago using sedimentation-rate data; this horizon can be correlated biostratigraphically (Morley, this volume) with the $2.41 \mathrm{~m}$.y. old IRD-rich horizon at Site 580. Given uncertainties in the sedimentation rates used to determine ages for these samples, these two earliest occurrences may both reflect the ice-rafting increase shown at approximately 2.45 m.y. ago on the general North Pacific curve (Kent et al., 1971). In fact, the first IRD at Sites 579 and 580 occurs near the Gauss/Matuyama magnetic boundary (see Site 579 and Site 580 chapters, this volume). The paleoposition estimates (Table 2) suggest that Site 579 entered the zone of "rare" ice-rafting (Conolly and Ewing, 1970; Fig. 1) approximately 2.5 m.y. ago; as a result, the first appearance of IRD at Site 579 at this time may be controlled by either site location, climatic variation, or both. Site 580 entered the zone of "rare" ice rafting prior to $2.5 \mathrm{~m}$.y. ago, however, so that the first appearance of IRD at Site 5802.5 m.y. ago suggests the importance of climatic variation as the primary control at this time. Similar paleomagnetic ages of first IRD occurrence were reported by Kent et al. (1971) in the North Pacific, and by various investigators in the North Atlantic (Roberts et al., 1982; Shackleton et al., 1982; Schnitker, 1982). For these reasons, the first occurrence of IRD at Sites 579 and 580 appears to reflect a climatic, rather than a site paleoposition, control; as such, these data support a conclusion, also based on North Pacific ice-rafting data, that the onset of major Northern Hemisphere glaciation took place approximately 2.47 m.y. ago (the time of the Matuyama/Gauss reversal boundary; Rea and Schrader, in press).

\section{CONCLUSIONS}

On the basis of the abundance and composition of the $250 \mu \mathrm{m}-2 \mathrm{~mm}$ size fraction in samples from Sites 579 and 580, the following conclusions can be reached:

1. The records of ice rafting at Sites 579 and 580 reflect the major variations in ice-rafting importance observed elsewhere in the North Pacific. These variations include both a long-term increase in ice-rafting importance as sediment age decreases and eight short-term increases between 1.0 m.y. ago and the present. The lessdetailed nature of the record is a result of the long distance from the ice-rafting source areas to Sites 579 and 580 .

2. Biostratigraphic and paleomagnetic data place the first occurrence of ice-rafted debris at Sites 579 and 580 at the Matuyama/Gauss reversal boundary (approximately 2.47 m.y. ago). Similar ages of first IRD occurrence have been reported in the North Atlantic and elsewhere in the North Pacific. These data support a proposed age of approximately $2.47 \mathrm{~m}$.y. for the onset of major
Northern Hemisphere glaciation (Rea and Schrader, in press).

3. The coarse-sand fraction at Sites 579 and 580 contains a significant component of non-ice-rafted grains, suggesting that the weight percent of the coarse-sand fraction alone may not be a valid indicator of ice-rafting importance at these sites. The mode of origin and transport of the coarse sand grains must be considered, therefore, in studies of IRD. Near sources of ice rafting, the coarse-sand fraction may be dominated by IRD, as concluded by von Huene et al. (1973). At more distal locations, however, other components may become important within the coarse-sand fraction; their influence on the weight percent values must be removed in order to obtain an accurate measure of ice-rafting influence.

\section{ACKNOWLEDGMENTS}

The authors thank G. Ross Heath for suggesting this project, and D. K. Rea for helpful discussions of other ice-rafting studies. D. Bernosky assisted in analysis of the Site 579 samples. D. K. Rea and LaVerne Kulm provided helpful comments on the manuscript.

\section{REFERENCES}

Conolly, J. R., and Ewing, M., 1970. Ice-rafted detritus in northwest Pacific deep-sea sediments. In Hays, J. D. (Ed.), Geological Investigations of the North Pacific. Mem. Geol. Soc. Am., 126:219-231.

Griggs, G. B., and Kulm, L. D., 1969. Glacial marine sediments from the northeast Pacific. J. Sediment. Petrol., 39:1142-1148.

Kent, D., Opdyke, N. D., and Ewing, M., 1971. Climate change in the north Pacific using ice-rafted detritus as a climatic indicator. Geol. Soc. Am. Bull., 82:2741-2754.

Leinen, M., and Heath, G. R., 1981. Sedimentary indicators of atmospheric activity in the northern hemisphere during the Cenozoic. Paleogeogr., Paleoclimatol., Paleoecol., 36:1-11.

Rea, D. K., and Schrader, H., in press. Late Pliocene onset of glaciation: Ice rafting and diatom stratigraphy of North Pacific DSDP cores. Paleogeogr., Paleoclimatol., Paleoecol.

Roberts, D. G., Schnitker, D., Backman, J., Baldauf, J. G., Desprairies, A., et al., 1982. Leg 81 drills west margin Rockall Plateau. Geotimes, 27:21-23.

Shackleton, N. J., Backman, J., Kent, D., Imbrie, J., Pestiaux, P., Pisias, N. G., and Zimmerman, H. B., 1982. The evolution of climate response to orbital forcing: Results over three million years from DSDP Site 522A. (Paper presented at the International Symposium on Milankovitch and Climate: Understanding the Response to Orbital Forcing, Lamont-Doherty Geological Observatory, New York).

Schnitker, D., 1982. Regular fluctuations of northeast Atlantic environments-Miocene to Recent. EOS Trans. Am. Geophys. Union, 63:984. (Abstract)

van Andel, T. H., Heath, G. R., and Moore, T. C., Jr., 1975. Cenozoic history and paleoceanography of the central equatorial Pacific. Mem. Geol. Soc. Am., 143:1-134.

von Huene, R., Crouch, J., and Larson, E., 1976. Glacial advance in the Gulf of Alaska implied by ice-rafted material. In Cline, R. M., and Hays, J. D. (Eds.), Investigation of Late Quaternary Paleoceanography and Paleoclimatology. Mem. Geol. Soc. Am., 145: 411-422.

von Huene, R., Larson, E., and Crouch, J., 1973. Preliminary study of ice-rafted erratics as indicators of glacial advances in the Gulf of Alaska. In Kulm, L. D., von Huene, R., et al., Init. Repts. DSDP, 18: Washington (U.S. Govt. Printing Office), 835-842.

Date of Initial Receipt: 10 November 1983

Date of Acceptance: 2 October 1984 
APPENDIX

Coarse-Sand Fraction Abundance and Compositional Data

\begin{tabular}{|c|c|c|c|c|c|c|}
\hline \multirow{2}{*}{$\begin{array}{l}\text { Core-Section } \\
\text { (level in cm) }\end{array}$} & \multirow{2}{*}{$\begin{array}{l}\text { Sub-bottom } \\
\text { depth } \\
\text { (m) }\end{array}$} & \multirow{2}{*}{$\begin{array}{l}\text { Interpolated } \\
\text { age (1000 yr.) }\end{array}$} & \multirow{2}{*}{$\begin{array}{c}\text { Wt. \% } \\
250 \mu \mathrm{m}-2 \mathrm{~mm}\end{array}$} & \multicolumn{3}{|c|}{ Percent in $250 \mu \mathrm{m}-2 \mathrm{~mm}$ fraction ${ }^{\mathrm{a}}$} \\
\hline & & & & $\%$ IRD & $\%$ Volcanics & $\%$ Biogeni \\
\hline \multicolumn{7}{|l|}{ Hole 579} \\
\hline $1-1,14$ & 0.14 & 3.3 & 0.02 & 1.0 & 3.0 & 96.0 \\
\hline $1-1,114$ & 1.14 & 27.1 & 0.06 & 0 & 6.5 & 93.5 \\
\hline $1-2,64$ & 2.14 & 51.0 & 0.04 & 0 & 0 & 100.0 \\
\hline $1-3,14$ & 3.14 & 74.8 & 0.05 & 0 & 30.9 & 69.1 \\
\hline $1-3,114$ & 4.14 & 98.6 & 0.01 & 0 & 1.0 & 99.0 \\
\hline $1-4,64$ & 5.14 & 122.4 & 0.14 & 0 & 0 & 100.0 \\
\hline $1-5,14$ & 6.14 & 146.2 & 0.01 & 0 & 0 & 100.0 \\
\hline $1-5,107$ & 7.07 & 168.3 & 0.07 & 1.2 & 5.8 & 93.0 \\
\hline $1-6,44$ & 7.94 & 189.0 & 0.03 & 1.4 & 7.0 & 91.6 \\
\hline $2-1,14$ & 8.54 & 203.3 & 0.04 & 9.1 & 9.1 & 81.8 \\
\hline $2-1,114$ & 9.54 & 227.1 & 0.04 & 9.6 & 13.5 & 76.9 \\
\hline $2-2,64$ & 10.54 & 251.0 & 0.12 & 0 & 0 & 100.0 \\
\hline $2-3,13$ & 11.53 & 274.5 & 0.02 & 0 & 1.0 & 99.0 \\
\hline $2-3,114$ & 12.54 & 298.6 & 0.03 & 0 & 21.7 & 78.3 \\
\hline $2-4,64$ & 13.54 & 322.4 & 0.13 & 4.0 & 26.0 & 70.0 \\
\hline $2-5,15$ & 14.55 & 346.4 & 0.12 & 0 & 1.0 & 99.0 \\
\hline $2-5,114$ & 15.54 & 370.0 & 0.02 & 1.0 & 6.0 & 93.0 \\
\hline $2-6,76$ & 16.66 & 396.7 & 0.17 & 2.0 & 2.0 & 96.0 \\
\hline
\end{tabular}

Hole 579A

\begin{tabular}{|c|c|c|c|c|c|c|}
\hline $1-1,51$ & 14.51 & 345.5 & 0.12 & 0 & 39.1 & 60.9 \\
\hline $1-1,136$ & 15.36 & 365.7 & 0.10 & 0 & 5.0 & 95.0 \\
\hline $1-2,91$ & 16.41 & 390.7 & 0.08 & 0 & 100.0 & 0 \\
\hline $1-3,51$ & 17.51 & 416.9 & 0.19 & 0 & 94.1 & 5.9 \\
\hline $1-3,136$ & 18.36 & 437.1 & 0.08 & 0 & 50.0 & 50.0 \\
\hline $1-4,96$ & 19.46 & 463.3 & 0.11 & 0 & 20.0 & 80.0 \\
\hline $1-5,51$ & 20.51 & 488.3 & 0.14 & 4.2 & 10.4 & 85.4 \\
\hline $1-5,136$ & 21.36 & 509.0 & 0.11 & 16.7 & 66.7 & 16.7 \\
\hline $1-6,81$ & 22.31 & 531.7 & 0.15 & 0 & 50.0 & 50.0 \\
\hline $2-1,31$ & 23.81 & 567.4 & 6.50 & 0 & 100.0 & 0 \\
\hline $2-1,131$ & 24.81 & 591.2 & 0.08 & 0 & 75.0 & 25.0 \\
\hline $2-2,81$ & 25.81 & 615.1 & 0.14 & 16.7 & 56.2 & 37.5 \\
\hline $2-3,31$ & 26.81 & 638.9 & 0.01 & 8.8 & 91.2 & 0 \\
\hline $2-3,131$ & 27.81 & 662.7 & 0.02 & 50.0 & 50.0 & 0 \\
\hline $2-4,71$ & 28.71 & 684.2 & 0.03 & 15.4 & 53.8 & 30.8 \\
\hline $2-5,31$ & 29.81 & 710.4 & 0.02 & 0 & 40.0 & 60.0 \\
\hline $2-5,131$ & 30.81 & 734.9 & 0.02 & 11.1 & 11.1 & 77.8 \\
\hline $2-6,81$ & 31.81 & 765.2 & 0.10 & 23.1 & 46.2 & 30.8 \\
\hline $2-7,31$ & 32.81 & 795.6 & 0.03 & 16.7 & 33.3 & 50.0 \\
\hline $3-1,2$ & 33.02 & 802.0 & 0.06 & 0 & 100.0 & 0 \\
\hline $3-1,101$ & 34.01 & 832.1 & 0.05 & 10.0 & 80.0 & 10.0 \\
\hline $3-2,51$ & 35.01 & 862.5 & 0.01 & 0 & 100.0 & 0 \\
\hline $3-3,9$ & 36.09 & 895.3 & 0.07 & 2.2 & 19.6 & 78.3 \\
\hline $3-3,109$ & 37.09 & 925.7 & 0.01 & 0 & 0 & 100.0 \\
\hline $3-4,59$ & 38.09 & 956.1 & 0.05 & 13.3 & 60.0 & 26.7 \\
\hline $3-5,13$ & 39.13 & 987.8 & 0.05 & 0 & 50.0 & 50.0 \\
\hline $3-5,113$ & 40.13 & 1018.1 & 0.06 & 10.0 & 90.0 & 0 \\
\hline $3-6,65$ & 41.15 & 1049.1 & 0.03 & 0 & 4.9 & 95.1 \\
\hline $4-1,2$ & 42.52 & 1090.8 & 0.25 & 10.0 & 80.0 & 10.0 \\
\hline $4-1,116$ & 43.66 & 1125.4 & 0.01 & 0 & 70.0 & 30.0 \\
\hline $4-2,49$ & 44.49 & 1150.7 & 0.02 & 20.0 & 80.0 & 0 \\
\hline $4-3,2$ & 45.52 & 1182.0 & 0.01 & 9.5 & 90.5 & 0 \\
\hline $4-3,102$ & 46.54 & 1213.0 & 0.01 & 1.0 & 2.0 & 97.0 \\
\hline $4-4,43$ & 47.43 & 1240.0 & 0.01 & 16.0 & 0 & 84.0 \\
\hline $5-1,7$ & 52.07 & 1381.1 & 0.01 & 0 & 0 & 100.0 \\
\hline $5-1,107$ & 53.07 & 1411.4 & 0.01 & 6.7 & 46.7 & 46.6 \\
\hline $5-2,69$ & 54.19 & 1445.5 & 0.09 & 0 & 90.9 & 9.1 \\
\hline $5-3,11$ & 55.11 & 1473.5 & 0.00 & - & - & - \\
\hline $5-3,98$ & 55.98 & 1499.9 & 0.07 & 37.5 & 37.5 & 25.0 \\
\hline $5-4,65$ & 57.15 & 1535.5 & 0.06 & 0 & 60.0 & 40.0 \\
\hline $5-5,21$ & 58.21 & 1567.7 & 0.07 & 0 & 0 & 100.0 \\
\hline $5-5,115$ & 59.15 & 1596.3 & 0.03 & 2.0 & 4.0 & 94.0 \\
\hline $5-6,65$ & 60.15 & 1626.6 & 0.03 & 0 & 0 & 100.0 \\
\hline $6-1,18$ & 61.68 & 1673.2 & 0.09 & 5.2 & 30.1 & 64.7 \\
\hline $6-1,126$ & 62.76 & 1706.0 & 0.07 & 10.0 & 50.0 & 40.0 \\
\hline $6-2,57$ & 63.57 & 1730.6 & 0.04 & 4.8 & 11.9 & 83.3 \\
\hline $6-3,8$ & 64.58 & 1761.3 & 0.03 & 4.4 & 8.8 & 86.8 \\
\hline $6-3,107$ & 65.57 & 1791.4 & 0.07 & 0 & 25.0 & 75.0 \\
\hline $6-4,48$ & 66.48 & 1819.0 & 0.02 & 9.1 & 45.4 & 45.4 \\
\hline $6-5,7$ & 67.57 & 1852.2 & 0.14 & 0 & 2.0 & 98.0 \\
\hline $6-5,115$ & 68.65 & 1885.0 & 0.17 & 1.8 & 5.4 & 92.8 \\
\hline $7-1,21$ & 71.21 & 1962.8 & 0.11 & 0 & 25.0 & 75.0 \\
\hline $7-1,121$ & 72.21 & 1993.2 & 0.01 & 2.0 & 4.0 & 94.0 \\
\hline
\end{tabular}


Appendix. (Continued).

\begin{tabular}{|c|c|c|c|c|c|c|}
\hline \multirow{2}{*}{$\begin{array}{l}\text { Core-Section } \\
\text { (level in } \mathrm{cm} \text { ) }\end{array}$} & \multirow{2}{*}{$\begin{array}{l}\text { Sub-bottom } \\
\text { depth } \\
\text { (m) }\end{array}$} & \multirow{2}{*}{$\begin{array}{l}\text { Interpolated } \\
\text { age (1000 yr.) }\end{array}$} & \multirow{2}{*}{$\begin{array}{c}\text { Wt. } \% \\
250 \mu \mathrm{m}-2 \mathrm{~mm}\end{array}$} & \multicolumn{3}{|c|}{ Percent in $250 \mu \mathrm{m}-2 \mathrm{~mm}$ fraction $^{\mathrm{a}}$} \\
\hline & & & & $\%$ IRD & $\%$ Volcanics & $\%$ Biogenic \\
\hline \multicolumn{7}{|c|}{ Hole 579A (Cont.) } \\
\hline $7-2,71$ & 73.21 & 2023.6 & 0.03 & 2.0 & 1.0 & 97.0 \\
\hline $7-3,31$ & 74.31 & 2057.0 & 0.17 & 0 & 40.0 & 60.0 \\
\hline $7-3,131$ & 75.31 & 2087.4 & 0.44 & 0 & 0 & 100.0 \\
\hline $7-4,82$ & 76.32 & 2118.1 & 0.00 & - & - & $\overline{-}$ \\
\hline $7-5,31$ & 77.31 & 2148.2 & 0.04 & 0 & 27.3 & 72.7 \\
\hline $7-5,131$ & 78.31 & 2178.6 & 0.05 & 0 & 33.3 & 66.7 \\
\hline $7-6,69$ & 79.19 & 2205.4 & 0.09 & 0 & 1.6 & 98.4 \\
\hline $8-1,23$ & 80.73 & 2252.2 & 0.12 & 4.0 & 31.0 & 65.0 \\
\hline $8-1,123$ & 81.73 & 2282.6 & 0.06 & 13.3 & 52.0 & 34.7 \\
\hline $8-2,75$ & 82.75 & 2313.6 & 0.02 & 0 & 0 & 100.0 \\
\hline $8-3,23$ & 3.73 & 2343.4 & 0.01 & 0 & 3.0 & 97.0 \\
\hline $8-3,123$ & 84.73 & 2373.7 & 0.05 & 0 & 10.0 & 90.0 \\
\hline $8-4,73$ & 85.73 & 2404.2 & 0.01 & 11.8 & 29.4 & 58.8 \\
\hline $8-5,23$ & 86.73 & 2434.6 & 0.14 & 14.0 & 3.0 & 83.0 \\
\hline $8-5,115$ & 87.65 & 2462.5 & 0.04 & 0 & 20.0 & 80.0 \\
\hline $8-6,73$ & 88.73 & 2489.3 & 0.07 & 6.2 & 25.0 & 68.8 \\
\hline $8-7,23$ & 89.73 & 2523.7 & 0.14 & 0 & 0 & 100.0 \\
\hline $9-1,19$ & 90.19 & 2539.5 & 0.05 & 0 & 74.0 & 26.0 \\
\hline $9-1,119$ & 91.19 & 2573.8 & 0.06 & 0 & 30.0 & 70.0 \\
\hline $9-2,61$ & 92.11 & 2605.4 & 0.08 & 0 & 4.0 & 96.0 \\
\hline $9-3,19$ & 93.19 & 2642.6 & 0.11 & 0 & 5.0 & 95.0 \\
\hline $9-3,111$ & 94.11 & 2674.2 & 0.02 & 0 & 77.7 & 22.2 \\
\hline $9-4,131$ & 95.81 & 2732.6 & 0.14 & 0 & 85.7 & 14.3 \\
\hline $9-5,19$ & 96.19 & 2745.7 & 0.10 & 0 & 54.5 & 45.5 \\
\hline $9-5,11$ & 97.11 & 2777.3 & 0.14 & 0 & 46.7 & 53.3 \\
\hline $10-1,21$ & 99.71 & 2866.6 & 0.03 & 0 & 83.3 & 16.7 \\
\hline $10-1,121$ & 100.71 & 2901.0 & 0.06 & 0 & 6.2 & 93.8 \\
\hline $10-2,71$ & 101.71 & 2935.4 & 0.19 & 0 & 0 & 100.0 \\
\hline $10-3,21$ & 102.71 & 2969.7 & 0.12 & 0 & 100.0 & 0 \\
\hline $10-3,121$ & 103.71 & 3004.1 & 0.09 & 0 & 48.0 & 52.0 \\
\hline $10-4,71$ & 104.71 & 3039.5 & 0.12 & 0 & 75.0 & 25.0 \\
\hline $10-5,21$ & 105.71 & 3072.8 & 0.02 & 0 & 4.4 & 85.6 \\
\hline $10-5,116$ & 106.66 & 3105.4 & 0.01 & 0 & 40.0 & 60.0 \\
\hline $11-1,21$ & 109.21 & 3193.1 & 0.05 & 0 & 0 & 100.0 \\
\hline $11-1,121$ & 110.21 & 3227.4 & 0.06 & 0 & 6.7 & 93.3 \\
\hline $11-2,71$ & 111.21 & 3261.8 & 0.03 & 0 & 46.7 & 53.3 \\
\hline $11-3,21$ & 112.21 & 3296.2 & 0.10 & 0 & 3.0 & 97.0 \\
\hline $11-3,121$ & 113.21 & 3330.5 & 0.05 & 0 & 3.2 & 96.8 \\
\hline $11-4,69$ & 114.19 & 3364.2 & 0.04 & 0 & 27.3 & 72.7 \\
\hline $11-5,39$ & 115.39 & 3393.8 & 0.04 & 0 & 12.2 & 87.8 \\
\hline $11-5,76$ & 115.76 & 3404.7 & 0.08 & 0 & 14.9 & 85.1 \\
\hline $12-1,10$ & 118.60 & 3488.2 & 0.09 & 0 & 28.6 & 71.4 \\
\hline $12-1,113$ & 119.63 & 3518.5 & 0.06 & 0 & 6.0 & 94.0 \\
\hline $12-2,56$ & 120.56 & 3545.9 & 0.02 & 0 & 33.3 & 66.7 \\
\hline $12-3,14$ & 121.64 & 3577.6 & 0.02 & 0 & 27.8 & 72.2 \\
\hline $12-3,113$ & 122.63 & 3606.8 & 0.06 & 0 & 2.5 & 97.5 \\
\hline $12-4,56$ & 123.56 & 3634.1 & 0.10 & 0 & 33.3 & 66.7 \\
\hline $12-5,10$ & 124.60 & 3664.7 & 0.17 & 0 & 0 & 100.0 \\
\hline $12-5,113$ & 125.63 & 3695.0 & 0.03 & 0 & 18.8 & 81.2 \\
\hline $12-6,34$ & 126.34 & 3715.9 & 0.03 & 0 & 7.1 & 92.9 \\
\hline \multicolumn{7}{|l|}{ Hole 580} \\
\hline $1-1,20$ & 0.21 & 3.8 & 0.12 & 7.5 & 4.1 & 88.4 \\
\hline $1-1,120$ & 1.21 & 22.1 & 1.02 & 21.5 & 65.1 & 13.4 \\
\hline $1-2,70$ & 2.21 & 40.3 & 0.35 & 26.0 & 52.2 & 21.8 \\
\hline $2-1,32$ & 3.63 & 66.2 & 1.18 & 7.0 & 89.4 & 3.6 \\
\hline $2-1,130$ & 4.61 & 84.1 & 0.69 & 49.9 & 50.0 & 0.0 \\
\hline $2-2,80$ & 5.61 & 102.4 & 0.14 & 10.5 & 5.0 & 84.5 \\
\hline $2-3,30$ & 6.61 & 120.6 & 0.02 & 4.6 & 1.5 & 93.9 \\
\hline $2-3,130$ & 7.61 & 138.9 & 0.02 & 0.0 & 1.0 & 99.0 \\
\hline $2-4,76$ & 8.57 & 156.4 & 0.39 & 41.8 & 34.4 & 23.8 \\
\hline $2-5,30$ & 9.61 & 175.4 & 0.93 & 43.0 & 50.4 & 6.6 \\
\hline $2-5,135$ & 10.66 & 194.5 & 0.26 & 32.5 & 45.5 & 22.0 \\
\hline $2-6,40$ & 11.21 & 204.6 & 0.24 & 30.5 & 43.9 & 25.6 \\
\hline $3-1,45$ & 13.26 & 242.0 & 0.01 & 2.0 & 33.4 & 64.6 \\
\hline $3-1,145$ & 14.26 & 260.2 & 0.12 & 14.7 & 28.4 & 56.9 \\
\hline $3-2,100$ & 15.31 & 279.4 & 0.30 & 22.5 & 15.5 & 62.0 \\
\hline $3-3,45$ & 16.26 & 296.7 & 0.30 & 15.5 & 44.3 & 40.2 \\
\hline $3-3,145$ & 17.26 & 315.0 & 1.03 & 25.0 & 54.9 & 20.1 \\
\hline $3-4,80$ & 18.11 & 330.5 & 0.13 & 3.0 & 4.5 & 92.5 \\
\hline $3-5,45$ & 19.26 & 351.5 & 0.04 & 0.0 & 1.0 & 99.0 \\
\hline $3-5,110$ & 19.91 & 363.3 & 0.58 & 25.4 & 71.1 & 3.5 \\
\hline $3-6,80$ & 21.11 & 385.2 & 0.02 & 3.8 & 26.8 & 69.4 \\
\hline
\end{tabular}


Appendix. (Continued).

\begin{tabular}{|c|c|c|c|c|c|c|}
\hline \multirow{2}{*}{$\begin{array}{l}\text { Core-Section } \\
(\text { level in cm) }\end{array}$} & \multirow{2}{*}{$\begin{array}{l}\text { Sub-bottom } \\
\text { depth } \\
\text { (m) }\end{array}$} & \multirow{2}{*}{$\begin{array}{l}\text { Interpolated } \\
\text { age (1000 yr.) }\end{array}$} & \multirow{2}{*}{$\begin{array}{c}\text { Wt. } \% \\
250 \mu \mathrm{m}-2 \mathrm{~mm}\end{array}$} & \multicolumn{3}{|c|}{ Percent in $250 \mu \mathrm{m}-2 \mathrm{~mm}$ fraction ${ }^{\mathrm{a}}$} \\
\hline & & & & $\%$ IRD & $\%$ Volcanics & $\%$ Biogenic \\
\hline \multicolumn{7}{|l|}{ Hole 580 (Cont.) } \\
\hline $4-1,28$ & 22.59 & 412.2 & 0.65 & 1.2 & 36.8 & 62.0 \\
\hline $4-1,130$ & 23.61 & 430.8 & 0.26 & 28.1 & 32.7 & 39.2 \\
\hline $4-2,70$ & 24.51 & 447.3 & 0.09 & 9.1 & 4.5 & 86.4 \\
\hline $4-3,28$ & 25.59 & 467.0 & 0.11 & 49.6 & 22.2 & 28.1 \\
\hline $4-3,130$ & 26.61 & 485.6 & 0.00 & 5.6 & 38.8 & 55.6 \\
\hline $4-4,70$ & 27.51 & 502.0 & 0.07 & 2.5 & 5.0 & 92.5 \\
\hline $4-5,28$ & 28.59 & 521.7 & 0.05 & 34.8 & 7.4 & 57.8 \\
\hline $4-5,130$ & 29.61 & 540.3 & 0.03 & 80.9 & 12.4 & 6.7 \\
\hline $4-6,74$ & 30.55 & 557.5 & 0.03 & 13.4 & 14.5 & 72.0 \\
\hline $5-1,28$ & 32.09 & 585.6 & 0.03 & 37.0 & 63.0 & 0.0 \\
\hline $5-1,135$ & 33.16 & 605.1 & 0.15 & 35.0 & 36.1 & 28.9 \\
\hline $5-2,70$ & 34.04 & 621.2 & 0.07 & 58.8 & 32.9 & 8.3 \\
\hline $5-3,28$ & 35.09 & 640.3 & 0.07 & 47.7 & 41.2 & 11.1 \\
\hline $5-3,135$ & 36.16 & 659.8 & 0.02 & 6.2 & 31.2 & 62.6 \\
\hline $5-4,83$ & 37.14 & 677.7 & 0.48 & 51.0 & 49.0 & 0.0 \\
\hline $5-5,28$ & 38.09 & 695.1 & 0.00 & - & - & - \\
\hline $5-5,110$ & 38.91 & 710.0 & 0.17 & 2.9 & 5.2 & 92.0 \\
\hline $6-1,9$ & 41.40 & 760.1 & 0.33 & 15.3 & 28.3 & 56.4 \\
\hline $6-1,106$ & 42.37 & 780.6 & 0.17 & 3.8 & 1.3 & 94.9 \\
\hline $6-2,60$ & 43.41 & 802.9 & 0.50 & 78.8 & 15.8 & 5.4 \\
\hline $6-3,9$ & 44.40 & 824.0 & 0.11 & 32.0 & 67.0 & 1.0 \\
\hline $6-3,106$ & 45.37 & 844.7 & 0.07 & 2.4 & 10.7 & 86.9 \\
\hline $6-4,52$ & 46.33 & 865.3 & 0.04 & 2.9 & 17.4 & 79.7 \\
\hline $6-5,9$ & 47.40 & 888.1 & 0.55 & 0.0 & 21.0 & 79.0 \\
\hline $6-5,106$ & 48.37 & 908.8 & 0.12 & 7.0 & 10.2 & 82.8 \\
\hline $6-6,60$ & 49.41 & 931.1 & 0.00 & - & - & - \\
\hline $7-1,13$ & 50.94 & 963.8 & 0.15 & 4.4 & 12.3 & 83.3 \\
\hline $7-1,115$ & 51.96 & 985.6 & 0.15 & 50.6 & 38.0 & 11.4 \\
\hline $7-2,86$ & 53.17 & 1011.4 & 0.13 & 3.3 & 95.7 & 1.3 \\
\hline $7-3,29$ & 54.10 & 1031.3 & 0.08 & 50.0 & 40.6 & 9.4 \\
\hline $7-3,110$ & 54.91 & 1048.6 & 0.67 & 20.9 & 56.9 & 22.2 \\
\hline $7-4,56$ & 55.87 & 1069.1 & 0.04 & 0.0 & 48.9 & 51.1 \\
\hline $7-5,22$ & 57.03 & 1184.7 & 0.02 & 0.0 & 20.2 & 79.8 \\
\hline $7-5,107$ & 57.88 & 1112.1 & 0.02 & 2.1 & 7.2 & 90.7 \\
\hline $8-1,32$ & 60.63 & 1170.8 & 0.02 & 0.0 & 1.0 & 99.0 \\
\hline $8-1,110$ & 61.41 & 1187.5 & 0.02 & 0.0 & 36.0 & 64.0 \\
\hline $8-2,60$ & 62.41 & 1208.8 & 0.00 & - & - & - \\
\hline $8-3,24$ & 63.55 & 1233.2 & 0.04 & 0.0 & 1.0 & 99.0 \\
\hline $8-3,110$ & 64.41 & 1251.6 & 0.10 & 10.7 & 29.9 & 59.4 \\
\hline $8-4,68$ & 65.49 & 1274.7 & 0.00 & - & - & - \\
\hline $8-5,24$ & 66.55 & 1297.3 & 0.00 & - & - & - \\
\hline $8-5,120$ & 67.51 & 1317.8 & 0.01 & 0.0 & 2.6 & 97.4 \\
\hline $8-6,60$ & 68.41 & 1337.1 & 0.04 & 0.0 & 1.0 & 99.0 \\
\hline $9-1,19$ & 70.00 & 1371.0 & 0.06 & 13.1 & 47.5 & 39.4 \\
\hline $9-1,102$ & 70.83 & 1388.8 & 0.19 & 0.0 & 1.0 & 99.0 \\
\hline $9-2,56$ & 71.87 & 1411.0 & 0.04 & 31.6 & 41.9 & 26.5 \\
\hline $9-3,19$ & 73.00 & 1435.1 & 0.29 & 0.0 & 4.8 & 95.2 \\
\hline $9-3,90$ & 73.71 & 1450.3 & 0.00 & - & - & - \\
\hline $9-4,73$ & 75.04 & 1478.7 & 0.00 & - & - & - \\
\hline $9-5,31$ & 76.01 & 1499.4 & 0.00 & - & - & - \\
\hline $9-5,73$ & 76.44 & 1508.6 & 0.02 & 0.4 & 1.2 & 98.4 \\
\hline $10-1,30$ & 79.61 & 1576.4 & 0.07 & 21.4 & 31.6 & 47.0 \\
\hline $10-1,130$ & 80.61 & 1597.7 & 0.35 & 0.0 & 11.0 & 89.0 \\
\hline $10-2,80$ & 81.61 & 1619.1 & 0.13 & 0.0 & 1.0 & 99.0 \\
\hline $10-3,30$ & 82.61 & 1640.5 & 0.09 & 1.3 & 4.8 & 93.9 \\
\hline $10-3,130$ & 83.61 & 1661.8 & 0.00 & - & - & - \\
\hline $10-4,90$ & 84.71 & 1685.3 & 0.00 & - & - & - \\
\hline $10-5,30$ & 85.61 & 1704.6 & 0.05 & 0.0 & 14.1 & 85.9 \\
\hline $10-5,145$ & 86.76 & 1729.1 & 0.57 & 0.0 & 80.2 & 19.8 \\
\hline $10-6,45$ & 87.26 & 1739.8 & 0.02 & 0.0 & 1.0 & 99.0 \\
\hline $11-1,30$ & 89.11 & 1779.4 & 0.41 & 0.0 & 7.5 & 92.5 \\
\hline $11-1,120$ & 90.01 & 1789.6 & 0.12 & 5.0 & 3.8 & 91.2 \\
\hline $11-2,80$ & 91.11 & 1822.1 & 0.00 & - & - & - \\
\hline $11-3,30$ & 92.11 & 1843.5 & 0.00 & - & - & - \\
\hline $11-3,140$ & 93.21 & 1867.0 & 0.04 & 0.0 & 0.0 & 100.0 \\
\hline $11-4,80$ & 94.11 & 1886.2 & 0.11 & 2.0 & 3.6 & 94.4 \\
\hline $11-5,30$ & 95.11 & 1907.6 & 0.03 & 1.6 & 5.5 & 92.9 \\
\hline $11-5,110$ & 95.91 & 1924.7 & 0.03 & 13.3 & 13.4 & 73.3 \\
\hline $12-1,40$ & 98.71 & 1984.5 & 0.03 & 0.0 & 81.5 & 18.5 \\
\hline $12-1,145$ & 99.76 & 2006.9 & 0.12 & 0.0 & 0.0 & 100.0 \\
\hline $12-2,90$ & 100.71 & 2027.2 & 0.08 & 0.0 & & 100.0 \\
\hline $12-3,40$ & 101.71 & 2048.6 & 0.04 & 5.6 & 2.2 & 92.2 \\
\hline $12-3,145$ & 102.76 & 2071.0 & 0.37 & 4.8 & 31.4 & 63.8 \\
\hline $12-4,90$ & 103.71 & 2091.3 & 0.13 & 0.0 & 4.3 & 95.7 \\
\hline $12-5,40$ & 104.71 & 2112.7 & 0.15 & 0.0 & 1.0 & 99.0 \\
\hline
\end{tabular}


Appendix. (Continued).

\begin{tabular}{|c|c|c|c|c|c|c|}
\hline \multirow{2}{*}{$\begin{array}{l}\text { Core-Section } \\
\text { (level in cm) }\end{array}$} & \multirow{2}{*}{$\begin{array}{l}\text { Sub-bottom } \\
\text { depth } \\
\text { (m) }\end{array}$} & \multirow{2}{*}{$\begin{array}{l}\text { Interpolated } \\
\text { age (1000 yr.) }\end{array}$} & \multirow{2}{*}{$\begin{array}{c}\text { Wt. } \% \\
250 \mu \mathrm{m}-2 \mathrm{~mm}\end{array}$} & \multicolumn{3}{|c|}{ Percent in $250 \mu \mathrm{m}-2 \mathrm{~mm}$ fraction ${ }^{a}$} \\
\hline & & & & $\%$ IRD & $\%$ Volcanics & $\%$ Biogenic \\
\hline \multicolumn{7}{|c|}{ Hole 580 (Cont.) } \\
\hline $12-5,105$ & 105.36 & 2126.6 & 0.23 & 0.8 & 0.5 & 98.7 \\
\hline $12-6,90$ & 106.71 & 2155.4 & 0.23 & 0.0 & 8.9 & 91.1 \\
\hline $13-1,20$ & 108.01 & 2183.2 & 0.08 & 7.4 & 11.1 & 81.5 \\
\hline $13-1,120$ & 109.01 & 2204.6 & 0.12 & 0.0 & 0.0 & 100.0 \\
\hline $13-2,70$ & 110.01 & 2225.9 & 0.28 & 0.4 & 4.4 & 95.2 \\
\hline $13-3,20$ & 111.01 & 2247.3 & 0.24 & 0.0 & 1.0 & 99.0 \\
\hline $13-3,120$ & 112.01 & 2273.9 & 0.22 & 0.0 & 2.0 & 98.0 \\
\hline $13-4,70$ & 113.01 & 2295.3 & 0.40 & 0.0 & 0.0 & 100.0 \\
\hline $13-5,20$ & 114.01 & 2316.7 & 0.00 & - & - & - \\
\hline $13-5,120$ & 115.01 & 2338.2 & 0.02 & 0.0 & 1.1 & 98.9 \\
\hline $13-6,70$ & 116.01 & 2359.6 & 0.00 & - & - & - \\
\hline $14-1,8$ & 117.39 & 2389.2 & 0.11 & 0.0 & 0.0 & 100.0 \\
\hline $14-1,108$ & 118.39 & 2410.6 & 0.15 & 0.1 & 0.0 & 99.9 \\
\hline $14-2,80$ & 119.61 & 2436.8 & 0.00 & - & - & - \\
\hline $14-3,8$ & 120.39 & 2453.5 & 0.00 & - & - & - \\
\hline $14-3,108$ & 121.39 & 2475.0 & 0.09 & 0.0 & 1.5 & 98.5 \\
\hline $14-4,60$ & 122.41 & 2498.3 & 0.25 & 0.0 & 3.0 & 97.0 \\
\hline $14-5,8$ & 123.39 & 2521.8 & 0.04 & 0.0 & 27.0 & 73.0 \\
\hline $14-5,108$ & 124.39 & 2545.7 & 0.00 & 0.0 & 18.6 & 81.4 \\
\hline $14-6,60$ & 125.41 & 2570.2 & 0.02 & 0.0 & 3.5 & 96.5 \\
\hline $15-1,18$ & 126.99 & 2608.1 & 0.03 & 0.0 & 8.0 & 92.0 \\
\hline $15-1,114$ & 127.95 & 2631.0 & 0.00 & - & - & - \\
\hline $15-2,61$ & 128.92 & 2654.4 & 0.00 & - & - & - \\
\hline $15-3,1$ & 129.82 & 2676.0 & 0.00 & - & - & - \\
\hline $15-3,101$ & 130.82 & 2699.9 & 0.04 & 0.0 & 28.9 & 71.1 \\
\hline $15-4,61$ & 131.92 & 2726.3 & 0.00 & - & - & - \\
\hline $15-5,1$ & 132.82 & 2747.9 & 0.00 & - & - & - \\
\hline $15-5,102$ & 133.83 & 2772.1 & 0.00 & - & - & - \\
\hline $15-6,52$ & 134.83 & 2796.1 & 0.01 & 0.0 & 31.0 & 69.0 \\
\hline $16-1,10$ & 136.41 & 2834.0 & 0.24 & 2.1 & 25.7 & 72.2 \\
\hline $16-1,110$ & 137.41 & 2858.0 & 0.18 & 0.0 & 15.6 & 84.4 \\
\hline $16-2,57$ & 138.38 & 2881.2 & 0.00 & - & - & - \\
\hline $16-3,10$ & 139.41 & 2905.9 & 0.16 & 0.0 & 4.0 & 96.0 \\
\hline $16-3,110$ & 140.41 & 2929.9 & 0.00 & - & - & - \\
\hline $16-4,57$ & 141.38 & 2953.2 & 0.11 & 0.0 & 0.0 & 100.0 \\
\hline $16-5,10$ & 142.41 & 2977.9 & 0.00 & 0.0 & 100.0 & 0.0 \\
\hline $16-5,110$ & 143.41 & 3001.9 & 0.17 & 0.0 & 0.0 & 100.0 \\
\hline $16-6,57$ & 144.38 & 3025.1 & 0.20 & 0.0 & 14.0 & 86.0 \\
\hline $17-1,1$ & 145.82 & 3059.7 & 0.28 & 0.0 & 19.1 & 80.9 \\
\hline $17-1,103$ & 146.84 & 3084.1 & 0.00 & - & - & - \\
\hline $17-2,57$ & 147.88 & 3109.1 & 0.00 & - & - & - \\
\hline $17-3,1$ & 148.82 & 3131.6 & 0.15 & 0.0 & 0.8 & 99.2 \\
\hline $17-3,103$ & 149.84 & 3156.1 & 0.00 & - & - & - \\
\hline $17-4,57$ & 150.88 & 3181.0 & 0.13 & 0.0 & 10.4 & 89.6 \\
\hline $17-5,1$ & 151.82 & 3203.5 & 0.07 & 0.0 & 1.1 & 98.9 \\
\hline $17-5,106$ & 152.87 & 3228.7 & 0.14 & 0.0 & 14.5 & 85.5 \\
\hline
\end{tabular}

a Point count data recalculated on a "mudball"-free basis. 